\title{
Effects of geoclimatic factors on the variability in Pinus pinea cone, seed, and seedling traits in Turkey native habitats
}

\author{
Safa Balekoglu* ${ }^{*}$, Servet Caliskan and Hüseyin Dirik
}

\begin{abstract}
Background: Stone pine (Pinus pinea L.) is harvested for its edible kernels. It is an important forest tree species, and also plays an important role in afforestation. Successful afforestation activities strongly depend on the quality of seeds and seedlings. Five eastern native populations of stone pine were analyzed, in terms of their geographical and climatic parameters, in order to identify their cone, seed, pine nut, and seedling traits. With this regard, we aimed to contribute to the reforestation, yield, and breeding of this species.
\end{abstract}

Results: All native populations occur in the sub-humid bioclimatic zone, according to Emberger's bioclimatic classification, ranging 74.7-63.2 of Emberger's $Q$ Index value $(Q)$, which synthesizes humidity and temperature, with lower values indicating more arid conditions. With regard to geographical factors, altitude was found to have the greatest effect on cone diameter and seed weight, while there was a weak correlation of cone, seed, and pine nut dimension with longitude and latitude. In terms of climatic factors, $Q$ and mean of the maximum temperature of June, July, and August (ME) were found to be the main drivers behind significant effects in cone, seed, and pine nut morphometric traits. The most negative effect on seed number cone ${ }^{-1}(r:-0.897)$, pine nut number cone ${ }^{-1}$ $(r:-0.923)$, pine nut yield $(r:-0.903)$, and pine nut weight $(r:-0.878)$ was $Q$, whereas cone diameter, seed length, and seed weight were positively correlated with the ME (r: 0.939, $r: 0.889$, and $r: 0.866$, respectively). Cone and seed diameter and seed weight increased with decreasing summer drought index $(r:-0.806, r:-0.846$, and $r:-0.866$, respectively). Rainfall in the June of the third year prior to harvest time (RJ) had a negative effect on the percentage of sound seeds per cone. Annual rainfall in the third year prior to harvest time (AR) significantly affected pine nut weight (r: 0.889), although rainfall during summer had a negative effect. The empty seed ratio of the different populations ranged from 20 to 68\%, while considering all populations, the empty seed ratio was $46 \%$.

Conclusions: The study suggests that the $Q$ Index and ME should be taken into account to determine cone to pine nut yield. With this regard, plantations of stone pine should be established on sub-humid areas and $Q$ values should not exceed 75 .

Keywords: Bioclimatic zone, Emberger, Mediterranean, Stone pine, variation

\section{Background}

Broad range of ecological conditions could create a variety of ecotypes (Huang 1993). This could contribute to the differences in characteristics of species such as cone, seeds, and shape which are important parameters

* Correspondence: safa.balekoglu@istanbul.edu.tr

Faculty of Forestry, Silviculture Department, Istanbul University-Cerrahpasa, Bahcekoy, Sariyer, Istanbul, Turkey

\section{Springer Open}

(c) The Author(s). 2020 Open Access This article is licensed under a Creative Commons Attribution 4.0 International License, which permits use, sharing, adaptation, distribution and reproduction in any medium or format, as long as you give appropriate credit to the original author(s) and the source, provide a link to the Creative Commons licence, and indicate if changes were made. The images or other third party material in this article are included in the article's Creative Commons licence, unless indicated otherwise in a credit line to the material. If material is not included in the article's Creative Commons licence and your intended use is not permitted by statutory regulation or exceeds the permitted use, you will need to obtain permission directly from the copyright holder. To view a copy of this licence, visit http://creativecommons.org/licenses/by/4.0/. 
and autumn thermal oscillation, spring hydric index, and spring and summer precipitation are directly linked with cone production (Calama et al. 2007; Loewe-Muñoz et al. 2016).

Stone pine is one of the commercially and ecologically important forest trees. Nuts constitute the most important non-wood product obtained from Mediterranean forests (Calama et al. 2016); it is one of the most characteristic species in the Mediterranean basin, with its umbrella shape and its use in horticulture, being cultivated for ornamental purposes. The cones are harvested for their edible kernels (pine nuts), which have been used as a food item since Paleolithic times (Mutke et al. 2005). Stone pine nuts are among the most expensive nuts; this high price makes them attractive as a crop. The species performs well in poor or eroded soils; its resistance to pests and diseases reduces the need for cultivation practices, and its high resistance to drought makes it a good candidate for conversion to a horticultural crop. Around the Mediterranean Sea, there are about 700,000 ha of stone pine-dominated forests, stretching from the Atlantic coast in Portugal to the shores of the Black Sea and Mount Lebanon (Mutke et al. 2012). Its distribution is mainly concentrated in Spain (450,000 ha), Portugal (90, $000 \mathrm{ha})$, Turkey (50,000 ha), and Italy (40,000 ha) (Pereira et al. 2015).

Stone pine is characterized by high phenotypic plasticity and adaptability, but low genetic variability (LoeweMuñoz et al. 2016). Genetic variation is generally considered to be an important adaptation to environmental conditions. Genetically depauperate, but geographically widespread, species are rare, and no other abundant and widespread plant species has as little genetic diversity as the stone pine. However, the species does have a considerable amount of variation in its adaptive traits (Vendramin et al. 2008).

Besides, seed production of trees is key to regeneration of forests and to successful conservation management (Gonçalves and Pommerening 2012). Successful restoration and rehabilitation in Mediterranean areas greatly depends on the quality of the seeds and seedlings used (Boydak and Çalışkan 2014). Significant degradation of the vegetation across large areas of the Mediterranean Basin has called for rehabilitation using native coniferous and broadleaved species (Boydak et al. 2006). Stone pine has been used in a variety of remedial ways, such as for ecological restoration, watershed and soil protection, the stabilization of dunes, and afforestation in urban areas (Mutke et al. 2012; Boydak and Çalışkan 2014, 2015; Calıșkan and Boydak 2017). The first dune afforestation project using Pinus pinea is thought to have been by the Romans along the Turkey-Antalya (Köprüçay) coastline, in an effort to stop mass movement and to prevent invasions of their agricultural land (Boydak and Çalışkan 2014).

On the other hand, Mutke et al. (2005) stated that further efforts will be required in order to accurately estimate the impacts of temperature rise and changes in rainfall patterns on cone development yield in stone pines. In the last few decades, efforts have been made in Spain, Turkey, and Portugal to domesticate the species, including intensive planting, reproductive propagation by grafting selected clones for cone production (Mutke, cited in Calama et al. 2016), and by employing irrigation and fertilization techniques (Calama et al. 2007; Loewe-Muñoz et al. 2017). Despite this, the main crop of cones collected and marketed are from either natural forests or afforestations (Mutke et al. 2012).

There is limited literature concerning variations among native populations of the species, in terms of cone, seed, germination, and seedling traits, and their correlation with climatic variables (Baskin and Baskin 1998; Ganatsas et al. 2008). The aims of the present study were to determine (a) the variation in cone, seed, and seedling morphological traits between, and among, the eastern stone pine populations (specifically, in Turkey); and (b) the relationships among climatic and geographical variables with cone and seed traits. With this regard, the present study will contribute to the reforestation, yield, and breeding of this species.

\section{Materials and methods}

\section{Seed material collection}

Natural stands of stone pine were selected from five populations across Turkey (Fig. 1, Table 1). Mature cones were collected in December 2016 from 15 to 25 randomly selected, mature trees in each population, which were growing at a distance of at least $50-100 \mathrm{~m}$ from each other, in order to capture a range of genetic variation (Ürgenç 1982). Ten cones were collected per tree, each placed in separate, labeled cloth bags (to prevent mildew). The cones were transported to the laboratory where they were stored at room condition until analyzed (Buru et al. 2016). The seeds were then manually extracted from 50 randomly selected cones from each of the five populations.

In Table 1 , the coefficient ' $S$ ' explains the severity of the summer drought, with higher values indicating weak summer drought conditions. The coefficient ' $Q$ ' refers to climatic humidity and temperature, with lower values indicating more arid conditions. The coefficient ' $m$ ' represents the duration of the frost cycle, with higher values indicative of a shorter cycle (Dirik 2008).

We used Emberger's equation, which is commonly used for the Mediterranean region, to categorize the bioclimate (Daget et al. 1988), the pluviothermic quotient $(Q)$ calculated as: 


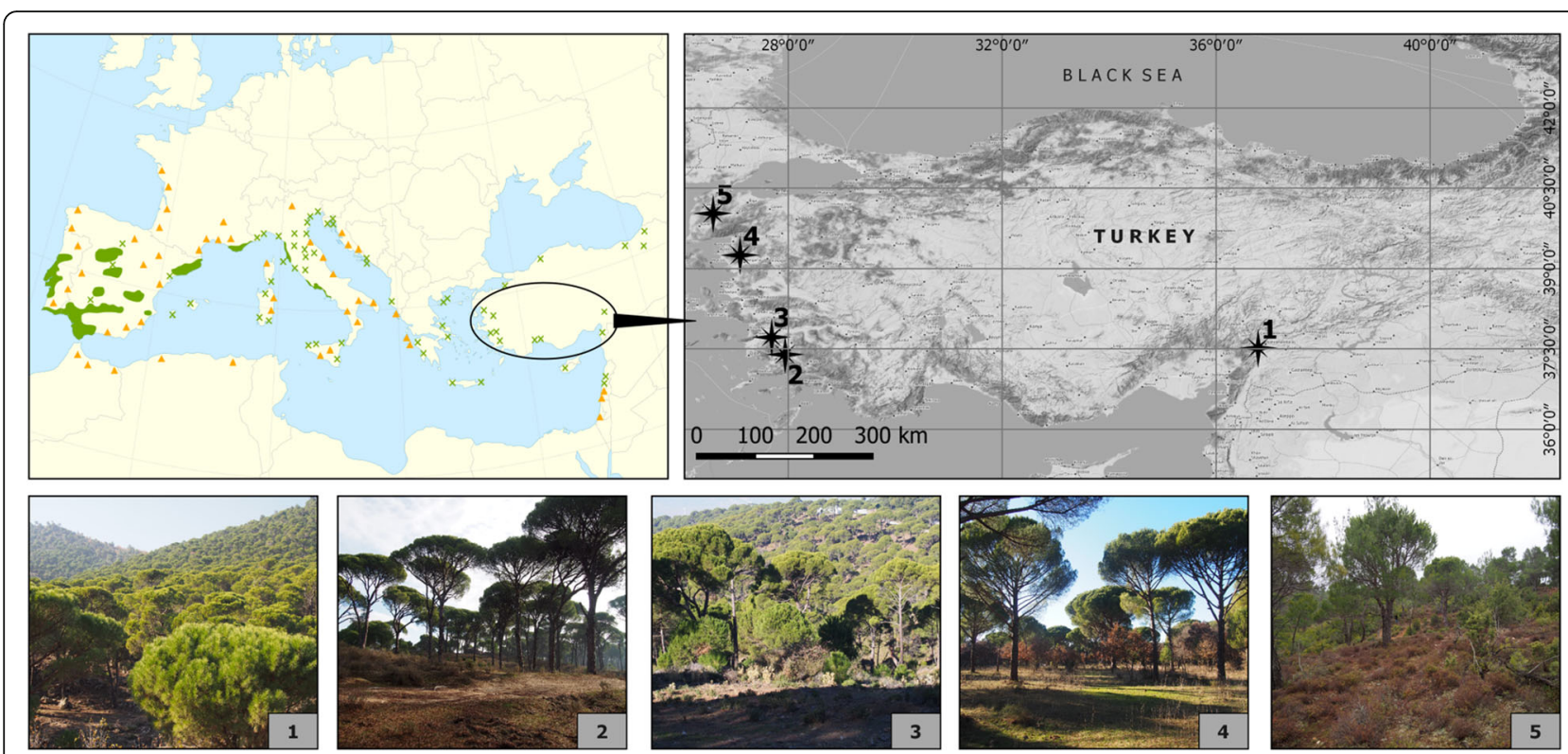

Fig. 1 Distribution map of stone pine (Pinus pinea) in Mediterranean Basin (upper left; modified from Caudullo et al. 2017, green and yellow color of icons indicate native/naturalized range, isolated populations and recently introduced/plantation, respectively). Geographic locations of five investigated natural stands of stone pine across Turkey (upper right); 1) K.Maraş-Önsen, 2) Muğla-Katrancı, 3) Aydın-Koçarlı, 4) İzmir-Kozak, and 5) Çanakkale-Kirazlı (photos taken by S. Balekoglu)

$$
Q=\frac{2000 P}{(M+m+546.24)(M-m)}
$$

where $P$ is the mean annual rainfall (in $\mathrm{mm}$ ), $M$ is the mean of the maximum temperatures in the hottest month (in ${ }^{\circ} \mathrm{C}$ ), and $m$ is the mean of the minimum temperatures in the coldest month (in ${ }^{\circ} \mathrm{C}$ ). The summer drought index (S) was calculated as $S=\mathrm{PE} / \mathrm{ME}$, where $\mathrm{PE}$ is the sum of the rainfall (in $\mathrm{mm}$ ) in June, July, and August, and ME is mean of the maximum temperatures in June, July, and August.

\section{Cone and seed measurements}

Fifty randomly selected cones, collected from 16 to 25 families in each population, were completely dissected to

Table 1 Some geographical and climatic characteristics of the five stone pine (Pinus pinea) populations across their natural distribution in Turkey

\begin{tabular}{|c|c|c|c|c|c|c|c|c|c|c|c|c|}
\hline & opulations & $\begin{array}{l}\text { Latitude } \\
\text { Longitude } \\
\text { Altitude } \\
\text { (m) }\end{array}$ & $\begin{array}{l}P \\
(\mathrm{~mm})\end{array}$ & $\begin{array}{l}\mathrm{M} \\
\left({ }^{\circ} \mathrm{C}\right)\end{array}$ & $\begin{array}{l}\mathrm{m} \\
\left({ }^{\circ} \mathrm{C}\right)\end{array}$ & $\begin{array}{l}\mathrm{PE} \\
(\mathrm{mm})\end{array}$ & $\begin{array}{l}\mathrm{ME} \\
\left({ }^{\circ} \mathrm{C}\right)\end{array}$ & $\mathrm{S}^{\mathrm{a}}$ & $\begin{array}{l}\text { Summer Drought } \\
\text { Index }^{\mathrm{a}}\end{array}$ & $Q^{a}$ & $\begin{array}{l}\text { Humidity } \\
\text { category }^{\mathrm{a}}\end{array}$ & $\begin{array}{l}\text { Climate } \\
\text { types }^{b}\end{array}$ \\
\hline 1 & K.Maraş-Önsen & $\begin{array}{l}37^{\circ} 30^{\prime} 27^{\prime \prime} \\
36^{\circ} 46^{\prime} 59^{\prime \prime} \\
800\end{array}$ & 742 & 36.6 & 1.5 & 7.4 & 40.3 & 0.18 & 2 & 72.39 & Sub-humid & Semi-arid \\
\hline 2 & $\begin{array}{l}\text { Muğla- } \\
\text { Yatağan }\end{array}$ & $\begin{array}{l}37^{\circ} 23^{\prime} 11^{\prime \prime} \\
27^{\circ} 56^{\prime} 22^{\prime \prime} \\
608\end{array}$ & 633 & 36.4 & 2.2 & 31.5 & 39.7 & 0.79 & 2 & 63.41 & Sub-humid & Semi-arid \\
\hline 3 & Aydın-Koçarlı & $\begin{array}{l}37^{\circ} 42^{\prime} 35^{\prime \prime} \\
27^{\circ} 41^{\prime} 18^{\prime \prime} \\
730\end{array}$ & 609 & 36.9 & 4.2 & 13.8 & 40.5 & 0.34 & 2 & 63.38 & Sub-humid & Semi-arid \\
\hline 4 & İzmir-Kozak & $\begin{array}{l}39^{\circ} 14^{\prime} 45^{\prime \prime} \\
27^{\circ} 05^{\prime} 50^{\prime \prime} \\
555\end{array}$ & 612 & 34.0 & 3.3 & 26.5 & 39.0 & 0.68 & 2 & 68.18 & Sub-humid & Semi-arid \\
\hline 5 & $\begin{array}{l}\text { Çanakkale- } \\
\text { Kirazlı }\end{array}$ & $\begin{array}{l}40^{\circ} 1^{\prime} 12^{\prime \prime} \\
26^{\circ} 35^{\prime} 36^{\prime \prime} \\
276\end{array}$ & 605 & 31.2 & 3.4 & 38.6 & 34.7 & 1.11 & 3 & 74.71 & Sub-humid & Semi-arid \\
\hline
\end{tabular}

$P$ mean annual rainfall in $\mathrm{mm} ; M$ the mean of the maxima of the hottest month; $m$ is the mean of the minima of the coldest month; $P E$ sum of rainfall in June, July, and August; ME mean of the maxima temperature of June, July, August for the period 1987-2016; $S$ summer drought index value; $Q$ humidity category value (for calculations, see the "Materials and methods" section).

aBioclimate zones according to Emberger (Daget et al. 1988)

${ }^{\mathrm{b}}$ Climate types according to Erinç's precipitation efficiency formula (Erinç 1965) 
determine the seed yields of the five populations. The seeds extracted from each cone were separately immersed in water to distinguish the sound (those that sank) seeds (Table 2). All the seed measurements were performed on a random sample of 10 seeds per cone (Ganatsas et al. 2008). The 1000-seed weight (1000-SW) was determined using the ISTA (1999) procedure.

\section{Seed germination}

Germination tests were performed in a growth chamber (model VT ${ }^{3}$ 4034; Vötsch Industrietechnik, Germany), maintained at 15,20 , and $25{ }^{\circ} \mathrm{C}$ until no additional seed germinated was observed. Randomly selected, sound seeds, with three replications $(3 \times 50)$ for each population, were used for germination. These were placed in 11-cm-diameter glass Petri dishes that were lined with two layers of filter paper, moistened with deionized water. The germinations were assessed daily, with germinated seeds being removed from the Petri dishes when their radicles had protruded (Farelli et al. 1997; Saracino et al. 2017). At the end of the test, the ungerminated seeds were subjected to a cut test to determine the proportion of sound to empty seeds in each replication of each treatment.

Stone pine seeds were also sown in the Forest Nursery Directorate in Bahçeköy/Sarıyer/Istanbul, Turkey at the beginning of March of 2017. The nursery is located at an altitude of $126 \mathrm{~m}$ above sea level at $41^{\circ} 10^{\prime} 56^{\prime \prime} \mathrm{N}$, $28^{\circ} 59^{\prime} 14^{\prime \prime} \mathrm{E}$, and the climate around the nursery is humid, mesothermal, and maritime, with a moderate deficit of water in the summer months, according to Thornthwaite's classification. The mean annual precipitation is about $1111.4 \mathrm{~mm}$, and the mean annual temperature is $12.8^{\circ} \mathrm{C}$ (Akburak et al. 2018).

Plastic containers $\left(18 \mathrm{~cm}\right.$ tall and $\left.190 \mathrm{~cm}^{3}\right)$, filled with conventional media (soil, peat, and river sand in a ratio of 2:1:1) were used for sowing the seeds. For the trial, a randomized block design, with five replications, was used $(135$ seeds $\times 5$ replications $\times 5$ populations $=3375$ sound seeds used). The germinations in the nursery were

Table 2 List of morphometric traits of $P$. pinea fruits and seedlings with measurement and units

\begin{tabular}{|c|c|c|c|}
\hline Morphometric & Abbreviation & Unit & Measurement \\
\hline \multicolumn{4}{|l|}{ Fruit traits } \\
\hline Cone diameter & $C D$ & $\mathrm{~mm}$ & Three measurements across the widest portion with a digital caliper \\
\hline Cone length & $\mathrm{CL}$ & $\mathrm{mm}$ & Measured using a digital caliper \\
\hline Cone weight & CW & g & 3-year-old cones were weighed with precision scale (accuracy of $0.01 \mathrm{~g}$ ) \\
\hline Seeds cone ${ }^{-1}$ & SN & No. & All seeds per cone were extracted and counted \\
\hline Empty seeds & ES & $\%$ & $E S=(S N-P N) / S N$ \\
\hline Seed yield & SY & $\%$ & $S Y=((S N \times S W) / C W) \times 100$ \\
\hline Seed diameter & SD & $\mathrm{mm}$ & Three measurements across the widest portion with a digital caliper \\
\hline Seed length & SL & $\mathrm{mm}$ & Measured using a digital caliper \\
\hline Seed weight & SW & g & Weighed with precision scale (accuracy of $0.01 \mathrm{~g}$ ) ${ }^{\mathrm{b}}$ \\
\hline Pine nuts cone $e^{-1}$ & PN & No. & All extracted seeds per cone were immersed and sinking seeds were counted \\
\hline Pine nut weight & PW & g & $\begin{array}{l}\text { Five sound seeds and empty seeds were weighed from each cone. } \\
\text { Calculated differences average five sound seeds weight and empty seeds } \\
\text { weight per cone. }\end{array}$ \\
\hline Pine nut yield & PY & $\%$ & $P Y=((P N \times P W) / C W) \times 100$ \\
\hline \multicolumn{4}{|l|}{ Seedling traits } \\
\hline Number of cotyledons & NC & No. & Counted in 175 seedlings ( 7 seedlings $\times 5$ replications $\times 5$ populations) \\
\hline Height & SdL1 & $\mathrm{cm}$ & Measured by scale at the end of first vegetation period in 175 seedlings \\
\hline Height & $\mathrm{SdL} 2$ & $\mathrm{~cm}$ & Measured by scale at the end of second vegetation period in 175 seedlings \\
\hline Root collar diameter & SdD1 & $\mathrm{mm}$ & Measured by digital caliper at the end of first vegetation period in 175 seedlings \\
\hline Root collar diameter & SdD2 & $\mathrm{mm}$ & Measured by digital caliper at the end of second vegetation period in 175 seedlings \\
\hline Lateral branches & LB1 & No. & Counted in 175 seedlings at the end of first vegetation period \\
\hline Lateral branches & LB2 & No. & Counted in 175 seedlings at the end of second vegetation period \\
\hline Bud set & BS & $\%$ & Observed in 175 seedlings at the end of second vegetation period ${ }^{c}$ \\
\hline
\end{tabular}

a,b Indicate $\approx 20 \%$ and $10 \%$ moisture content

${ }^{\mathrm{c}}$ No terminal bud observed at the first year 
recorded two times in a week until no further germinated was observed.

The germination percentage (GP) and mean germination time (MGT) for laboratory and field conditions (FGP and FMGT) were calculated thus:

GP or FGP $(\%)=G / T \times 100$

where $G$ is the total number of germinated seeds and $T$ is the total number of seeds; and

\section{MGT or FMGT $=\sum(t \times n) / \sum n$}

where $t$ is the number of days from the beginning of the test and $n$ is the number of germinated seeds on day $t$ (Bewley and Black 1994).

\section{Statistical analysis}

All statistical analyses were carried out using SPSS (2010) software. The GP and FGP data were arcsine transformed. The GP, FGP, MGT, and FMGT data of the five populations were analyzed using ANOVA. The following ANOVA models were used:

$$
Y_{i}=\mu+\phi_{\mathrm{i}}+\varepsilon_{\mathrm{ik}}
$$

where $Y_{\mathrm{i}}$ is the observed value of the cone, seed, and seedling traits; $\mu$ is the overall mean; $\phi_{\mathrm{i}}$ represents the effect of population; and $\varepsilon_{\mathrm{i}}$ is the effect caused by error. The populations were excepted as fixed factors; and

$$
\mathrm{Y}_{\mathrm{ik}}=\mu+\varphi_{\mathrm{i}}+\mathrm{T}_{\mathrm{k}}+\varphi \Phi_{\mathrm{ik}}+\varepsilon_{\mathrm{ik}}
$$

where $\gamma_{\mathrm{ik}}$ is the observed value of the germination traits; $\mu, \phi_{\mathrm{i}}, \quad \mathrm{k}$, and $\varepsilon_{\mathrm{ik}}$ are the overall mean, population effect, temperature effect, and error, respectively. The populations and temperatures were excepted as fixed factors. Duncan's post hoc test was used to determine homogeneous subgroups. Pearson's correlation coefficients between the cone, seed and seedling traits, germination values, and geographical and climatic variables were determined.

\section{Results}

The ANOVA results for the cone and seed traits showed significant differences among the five native populations from Turkey. The range of variation in the cone diameter $(\mathrm{CD})$, cone length $(\mathrm{CL})$, and cone weight $(\mathrm{CW})$ ranged from $48-87 \mathrm{~mm}, 58-150 \mathrm{~mm}$, and $82-435 \mathrm{~g}$, respectively. The seed diameter (SD), seed length (SL), and 1000-SW varied between 6.5 and $10.9 \mathrm{~mm}, 11.8$ and $22.4 \mathrm{~mm}$, and 589 and $903 \mathrm{~g}$, respectively. The pine nut yield (PY) was low in all the populations, ranging from 1.20 to $1.55 \%$, except for the Muğla-Katrancı (3.53\%) and Aydın-Koçarlı (4.47\%) populations (Table 3).

The empty seeds (ES) and seeds per cone (SN) were determined for the populations, and for the families within the populations. The minimum and maximum ES and SN were found between 20\% (Muğla-Katrancı) and
68\% (İzmir-Kozak), 25 (Çanakkale-Kirazlı) and 75 (Aydın-Koçarlı), respectively. Considering all the populations, the ES was $46 \%$ (Fig. 2).

The germinations in the growth chamber started at days 10,12 , and 15 , at 15,20 , and $25^{\circ} \mathrm{C}$, respectively, for the five stone pine seed lots. The effects of temperature were statistically significant for GP and MGT. Interaction between provenances and temperatures did not reveal any significant effect. The GP and MGT at $15{ }^{\circ} \mathrm{C}$ in the growth chamber showed significant differences among the five populations. The highest GP (93\%) and lowest MGT (12 days) were from the Aydın-Koçarl population at $20{ }^{\circ} \mathrm{C}$. The optimum seed germination temperature was $20{ }^{\circ} \mathrm{C}$ for all populations, except Mugla-Katrancl, which germinated $10 \%$ better at $15{ }^{\circ} \mathrm{C}$ than at $20^{\circ} \mathrm{C}$. The MGT values were the lowest for all populations at $20{ }^{\circ} \mathrm{C}$, and the mean MGT for the five populations was 13 days. The germinations in the field emerged at around 50 days (in May) after sowing (in March). The field germination percentage (FGP) and field mean germination time (FMGT) values were 50\% and 69 days, respectively; they showed no significant differences within the populations (Fig. 3, Table 4).

The number of cotyledons (NC) varied between 8 and 16. The highest NC (16) belonged to the K. MaraşÖnsen population. This population also had the tallest seedling height in the first year (SdL1). In the second year, the seedlings from the Izmir-Kozak population were the tallest $(38 \mathrm{~cm})$, with the K. Maraş-Önsen being the second tallest $(34 \mathrm{~cm})$. The Muğla-Katrancı population had the highest root-collar diameter in the first (SdD1) and second year (SdD2) (3.3 and $6.1 \mathrm{~mm}$, respectively). There was a relatively large variation in the number of lateral branches in the first (LB1) and second-year (LB2) seedlings. No terminal buds were observed in the populations in the first year. In the second year, no terminal buds were observed in the IzmirKozak population, while the other populations' bud sets (BS) ranged from 8 to 58\%. In the K. Maraş-Önsen population, more than half the seedlings formed terminal buds (Table 5).

According to the results of the correlation analysis, there were highly significant correlations between cone size and seed size. CD and CL had a significant (the strongest) positive effect on CW ( $r: 0.885$ and $r: 0.849$, respectively). SD and SL significantly affected the SW (r: 0.921 and $r: 0.866$, respectively). SL had a significant positive effect on $\mathrm{CD}$ and $\mathrm{CW}(r: 0.840$ and $r$ : 0.765, respectively). SN increased with increasing cone size. PY was negatively related to ES. In addition, PY had a significantly positive correlation with cone size, including CW and SL (Table 6).

The 1000-SW increased with increased altitude $(r$ : $0.866)$. SL and SD positively correlated with altitude $(r$ : 
Table 3 Cone and seed morphometric traits of five stone pine ( $P$. pinea) populations in Turkey

\begin{tabular}{|c|c|c|c|c|c|c|}
\hline \multirow[t]{2}{*}{ Parameters } & \multicolumn{5}{|l|}{ Populations } & \multirow[t]{2}{*}{ Mean } \\
\hline & 1 K.Maraş-Önsen & 2 Muğla-Katrancı & 3 Aydın-Koçarlı & 4 İzmir-Kozak & 5 Çanakkale-Kirazlı & \\
\hline$\overline{C D}$ & $77.2(65-85)^{b}$ & $74.5(56-85)^{\mathrm{b}}$ & $79.1(71-87)^{c}$ & $78.4(64-86)^{c}$ & $63.6(48-75)^{a}$ & $74.6(61-84)$ \\
\hline $\mathrm{CL}$ & $95.1(74-114)^{b}$ & $103.2(59-126)^{\mathrm{cd}}$ & $102.4(82-150)^{c}$ & $105.0(72-127)^{d}$ & $79.6(58-98)^{a}$ & $97.1(69-123)$ \\
\hline CW & $238.5(145-335)^{b}$ & $264.6(103-408)^{c}$ & $294.4(122-424)^{d}$ & $289.2(132-435)^{c d}$ & $167.8(82-279)^{\mathrm{a}}$ & $250.9(117-376)$ \\
\hline SD & $9.2(7.5-10.9)^{d}$ & $8.5(7.0-10.1)^{b}$ & $8.7(7.0-10.3)^{b}$ & $8.9(6.9-10.8)^{c}$ & $8.2(6.5-9.8)^{a}$ & $8.7(7.0-10.4)$ \\
\hline$S L$ & $17.8(13.7-21.6)^{b}$ & $17.9(14.2-21.7)^{\mathrm{b}}$ & $18.9(15.5-22.2)^{c}$ & $18.7(14.9-22.4)^{c}$ & $15.6(11.8-19.4)^{a}$ & $17.8(14.0-21.5)$ \\
\hline 1000-SW & $902.7(0.4-1.3)^{d}$ & $754.1(0.4-1.1)^{\mathrm{b}}$ & $844.2(0.5-1.2)^{c d}$ & $885.9(0.4-1.3)^{c}$ & $589.4(0.3-0.9)^{a}$ & $795.3(0.8)$ \\
\hline SN & $40(4-82)^{b}$ & $54(8-103)^{c}$ & $75(26-118)^{d}$ & $55(21-113)^{c}$ & $25(3-56)^{a}$ & $50(12-94)$ \\
\hline SY & $13.2(3-24)^{b}$ & $12.9(4-22)^{b}$ & $18.5(11-32)^{d}$ & $15.6(9-26)^{c}$ & $8.1(1-15)^{a}$ & $13.7(6-24)$ \\
\hline ES & $60(21-89)^{b}$ & $20(2-69)^{a}$ & $21(2-71)^{a}$ & $68(27-98)^{c}$ & $60(20-88)^{b}$ & $46(14-83)$ \\
\hline PN & $17(1-51)^{b}$ & $44(5-96)^{c}$ & $60(24-109)^{d}$ & $21(1-82)^{b}$ & $10(2-31)^{a}$ & $30(7-74)$ \\
\hline PW & $0.19(0.05-0.34)^{a}$ & $0.22(0.01-0.46)^{b c}$ & $0.23(0.01-0.62)^{c}$ & $0.23(0.05-0.35)^{c}$ & $0.18(0.05-0.36)^{a}$ & $0.21(0.03-0.43)$ \\
\hline PY & $1.37(0.15-4.90)^{\mathrm{a}}$ & $3.53(0.19-9.99)^{b}$ & $4.47(0.27-9.74)^{c}$ & $1.55(0.11-7.11)^{\mathrm{a}}$ & $1.20(0.12-3.61)^{\mathrm{a}}$ & $2.42(0.17-7.07)$ \\
\hline
\end{tabular}

Means in columns followed by the same letters are not statistically different at a 0.05 significance level using the Duncan post hoc test. For abbreviations, please see Table 2. Minimum and maximum values are presented in parentheses

0.771 and $r$ : 0.813 , respectively). CW, CL, and CD also positively correlated with altitude $(r: 0.683, r: 0.667$, and $r: 0.872$, respectively), but negatively with latitude $(r:-$ $0.552, r:-0.598$, and $r:-0.659$, respectively) (Table 7).

The correlation analysis revealed that ME had the most significant effect on CD and SL $(r: 0.939$ and $r$ : 0.889 , respectively), and also had a positive effect $(r$ : 0.866 ) on the 1000-SW, while summer drought index (S) had a negative effect on this $(r:-0.860)$. Although the sum of rainfall in June, July, and August (PE) and $S$ factors had a negative effect on the 1000-SW, the mean of the maxima of the hottest month $(\mathrm{M})$ had a positive effect ( $r: 0.723)$. $Q$ had substantial negative effects on SN $(r:-0.897), \mathrm{CW}(r:-0.820), \mathrm{CL}(r:-0.823)$, and CD $(r$ : $-0.25)$. $S$ had substantial negative effects on CD $(r$ : $0.806)$ and $\mathrm{SD}(r:-0.846) . Q$ had a significant negative effect on SN, pine nut per cone (PN), and PY $(r:-0.897$, $r:-0.923$, and $r:-0.903$, respectively). In addition, $Q$ had a negative correlation with all cone, seed, and pine nut parameters, except for ES, while ME positively correlated with all the parameters, except for ES. RJ had a negative influence on ES ( $r$ : 0.846), while AR is significantly related to pine nut weight (PW) $(r$ : 0.889) (Table 7).

The SdL1 affected the SdL2 ( $r: 0.760)$. LB2 had a substantial negative effect on the SdL1 and SdL2 $(r:-0.915$ and $r:-0.808$, respectively). The correlation coefficient between the number of cotyledons (NC) and the BS at the end of second year was $r: 0.876$. The longitudes of the five native stone pine populations positively correlated with $\mathrm{BS}$ and $\mathrm{NC}(r: 0.976$ and $r: 0.892$, respectively). The increasing altitude of the populations resulted in increased SdD1 and NC ( $r: 0.713$ and $r$ : 0.758 , respectively) (Table 8 ).

\section{Discussion}

\section{Cone traits}

The mean CW of $251 \mathrm{~g}$ is consistent with reported ranges of 227-304 g, based on 3-year surveys (Gonçalves and Pommerening 2012), and 250-350 g (Mutke et al. 2011), in their native habitat, while studies on populations in non-native habitats have indicated high mean CWs of $495 \mathrm{~g}$ (Loewe-Muñoz et al. 2018) and $521 \mathrm{~g}$ (Loewe-Muñoz et al. 2019). In the present study, the average CL $(9.7 \mathrm{~cm})$ and $\mathrm{CD}(7.5 \mathrm{~cm})$ are smaller than those reported by Loewe-Muñoz et al. (2018), which were $11.3 \mathrm{~cm}(\mathrm{CL})$ and $9.4 \mathrm{~cm}(\mathrm{CD})$, but were bigger than those from southern Greece (CL $8.3 \mathrm{~cm}$ and $\mathrm{CD}$ $6.8 \mathrm{~cm}$ ) (Ganatsas et al. 2008).

Stone pine cones have a 3-year reproductive development cycle, which begins when the female strobili (conelets) burst in the spring of the first year, with pollination occurring a few weeks after that. Strobilus fertilization, however, takes place only in the spring/summer of the third and final year of cone maturation, when the nutritious, edible seeds are formed (Valdiviesso et al. 2017). It is expected that a reduction in rainfall will have a negative effect on cone production. Calama and Montero (2007) indicated that spring and summer rainfall has a positive impact on cone production, meaning cone number per tree, CW, and PY. A decrease in stone pine seed production could also result from heavy rains during pollination (Parlak et al. 2013). In our study, rainfall in the June of the third year prior to the cone-collecting year (RJ) (Mutke et al. 2005), during pollination, is a climatic factor that might cause a decrease in the sound seed ratio. This supports the findings of Parlak et al. (2013), who highlighted the importance of the pollination period on cone production. They also pointed out 

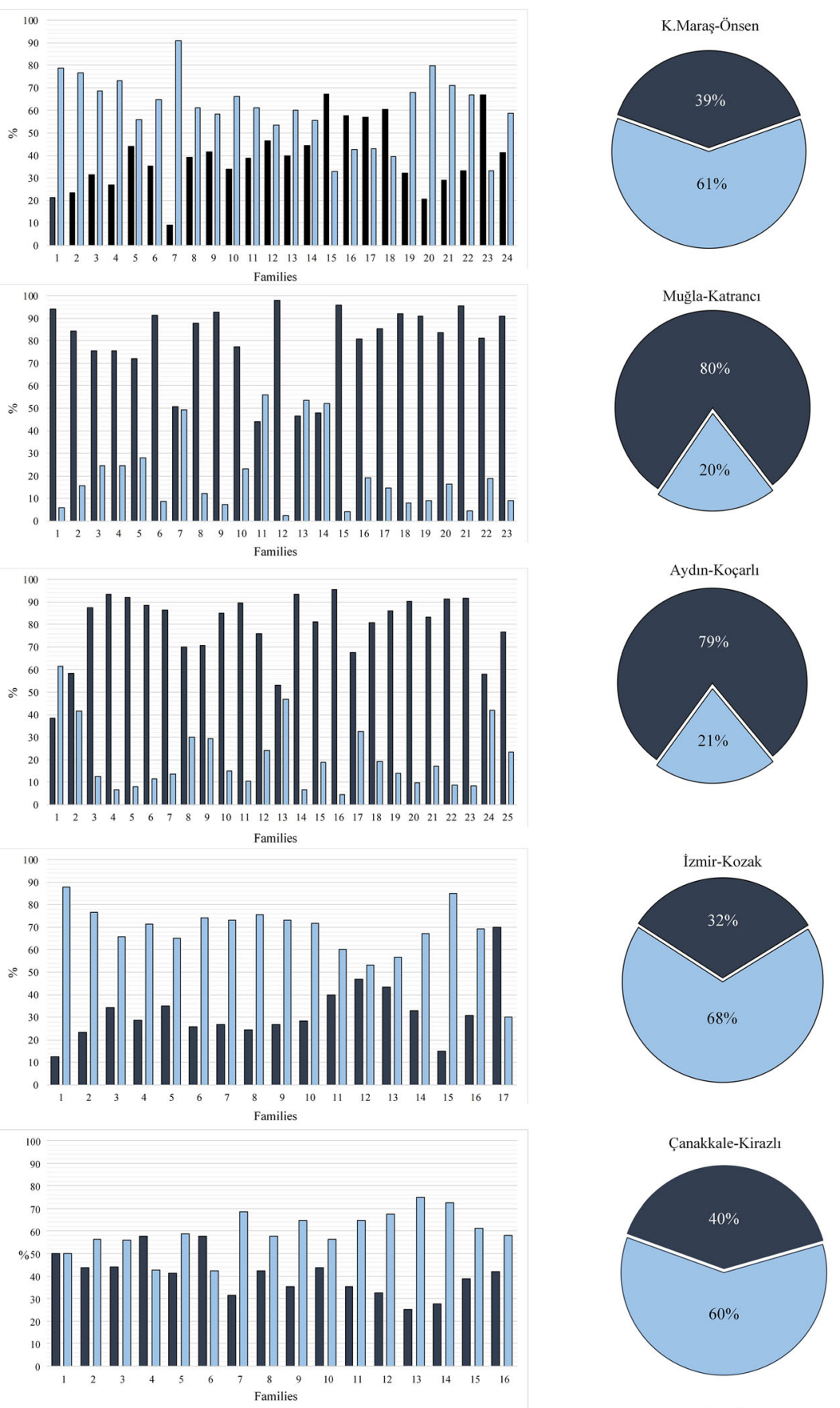

$$
\begin{aligned}
& \square \text { Sound } \\
& \square \text { Empty }
\end{aligned}
$$

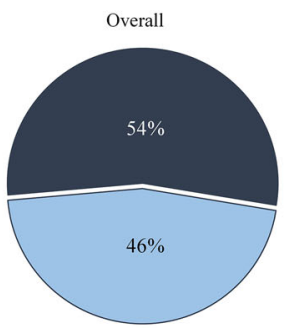

Fig. 2 Percentages of sound versus empty seeds among, and between, the five natural populations of P. pinea across Turkey 


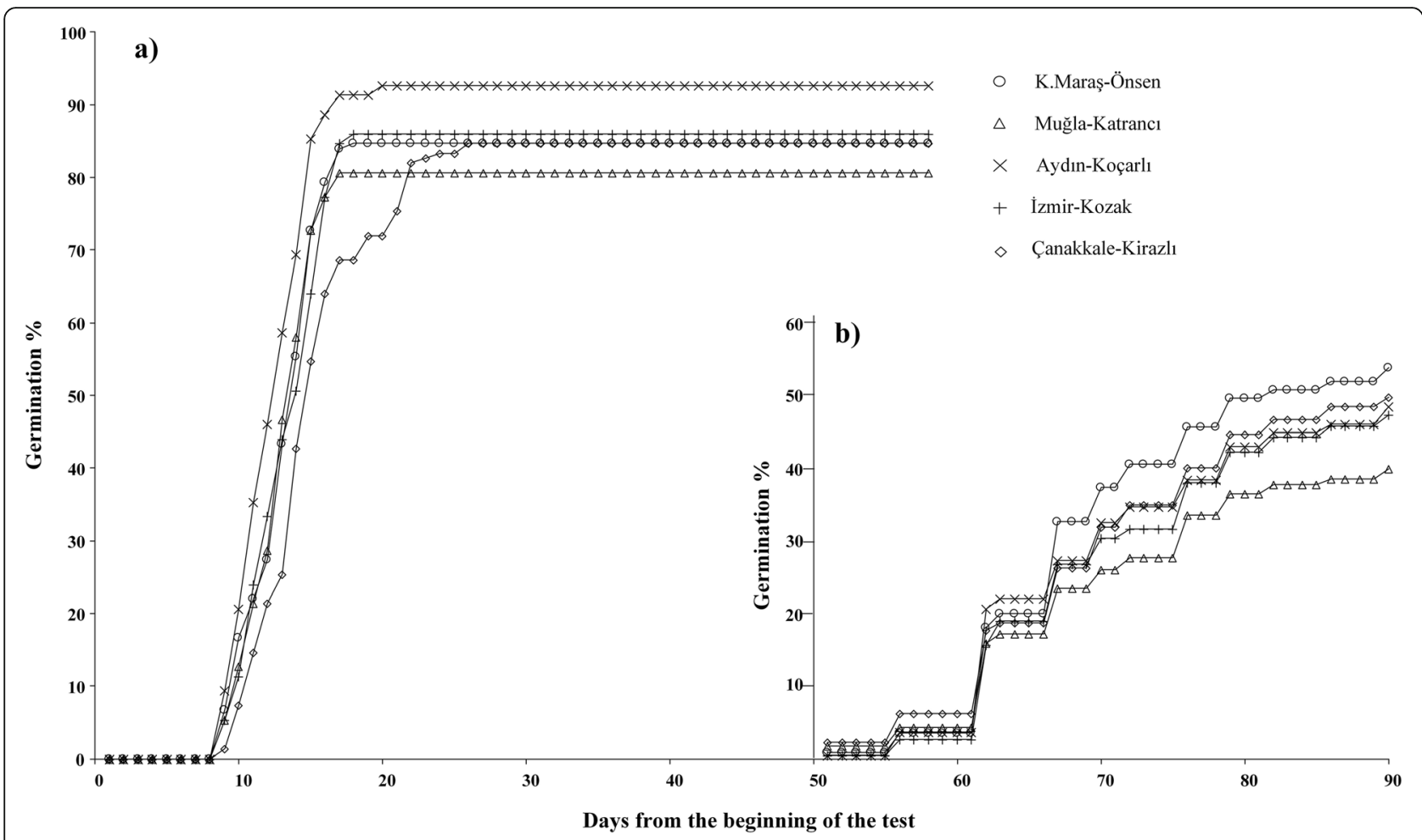

Fig. 3 Germination of P. pinea seeds from five natural populations in $\mathbf{a}$ the growth chamber $\left(20^{\circ} \mathrm{C}\right)$ and $\mathbf{b}$ the field

that non-productive areas located at altitudes below 500 m were identifiable by a thermal oscillation of $22{ }^{\circ} \mathrm{C}$ and a higher frequency of days with temperatures below 10 ${ }^{\circ} \mathrm{C}$, early and late frosts, high relative humidity, and fog. Annual rainfall in the third year prior to harvest time (AR) had a positive impact on CW, as also reported by Loewe-Muñoz et al. (2016). AR showing inter-annual variation has also been positively related to cone yield (Loewe-Muñoz et al. 2020).

The climatic factors $Q$ and ME were found to be the main drivers behind the stone pine cone, seed, and pine nut morphometric traits. The most significant limiting factors to annual cone yield appeared to be water stress during different stages of cone development and the negative effect of hot midsummers on cone setting (Mutke et al. 2005). Loewe-Muñoz et al. (2016) suggested that the selection of sites for fruiting should ensure minimum average spring temperatures above $7^{\circ} \mathrm{C}$, annual and autumn thermal oscillations below $12{ }^{\circ} \mathrm{C}$, and a high spring rainfall, except during the male flowering period. In the final year, losses in seed yield (with up to $50 \%$ of the seeds being empty) have been reported from Portugal, Spain, Italy, and Turkey (Mutke et al. 2014), but in Chilean plantations, the percentage of damaged/empty seeds was relatively very low, at around 9\% (Loewe-Muñoz et al. 2019). We found that the overall sound seed ratio was 54\%, ranging from 32 to $80 \%$. This ratio could change in the future because of stand

Table 4 Germination of $P$. pinea seeds from five natural populations at 15,20 , and $25^{\circ} \mathrm{C}$ and in the field

\begin{tabular}{|c|c|c|c|c|c|c|c|c|c|}
\hline \multirow{2}{*}{\multicolumn{2}{|c|}{ Populations }} & \multicolumn{4}{|l|}{ GP } & \multicolumn{4}{|l|}{ MGT } \\
\hline & & \multirow{2}{*}{$\frac{15^{\circ} \mathbf{C}}{83^{a b}}$} & \multirow{2}{*}{$\frac{20^{\circ} \mathrm{C}}{85^{\mathrm{a}}}$} & \multirow{2}{*}{$\frac{25^{\circ} \mathbf{C}}{12^{a}}$} & \multirow{2}{*}{$\frac{\text { Field }}{54^{\mathrm{a}}}$} & \multirow{2}{*}{$\frac{15^{\circ} \mathrm{C}}{27^{b c}}$} & \multirow{2}{*}{$\frac{20^{\circ} \mathrm{C}}{13^{a}}$} & \multirow{2}{*}{$\frac{25^{\circ} \mathrm{C}}{16^{\mathrm{a}}}$} & \multirow{2}{*}{$\frac{\text { Field }}{68^{a}}$} \\
\hline 1 & K.Maraş-Önsen & & & & & & & & \\
\hline 2 & Muğla-Katrancı & $91^{b}$ & $81^{\mathrm{a}}$ & $6^{a}$ & $40^{a}$ & $17^{\mathrm{a}}$ & $13^{a}$ & $15^{\mathrm{a}}$ & $69^{a}$ \\
\hline 3 & Aydın-Koçarlı & $82^{\mathrm{ab}}$ & $93^{a}$ & $5^{a}$ & $49^{a}$ & $21^{\mathrm{ab}}$ & $12^{a}$ & $18^{a}$ & $69^{a}$ \\
\hline 4 & İzmir-Kozak & $78^{a b}$ & $86^{a}$ & $8^{a}$ & $47^{\mathrm{a}}$ & $29^{c}$ & $13^{a}$ & $16^{a}$ & $69^{a}$ \\
\hline 5 & Çanakkale-Kirazlı & $68^{a}$ & $85^{a}$ & $4^{a}$ & $50^{a}$ & $29^{c}$ & $15^{b}$ & $21^{a}$ & $68^{a}$ \\
\hline \multicolumn{2}{|c|}{ Mean } & $80 \mathrm{~A}^{\prime}$ & $86 A^{\prime}$ & $7 B^{\prime}$ & $48 C^{\prime}$ & $25 \mathrm{~A}$ & $13 B$ & $17 \mathrm{C}$ & $69 \mathrm{D}$ \\
\hline
\end{tabular}

GP germination percentage, MGT mean germination time. Means in the same column followed by the same lowercase or uppercase letter are significantly different $(p<0.05)$ 
Table 5 Seedling traits of the five natural stone pine ( $P$. pinea) populations in Turkey

\begin{tabular}{|c|c|c|c|c|c|c|}
\hline \multirow[t]{2}{*}{ Parameters } & \multicolumn{5}{|l|}{ Populations } & \multirow[t]{2}{*}{ Mean } \\
\hline & 1 K.Maraş-Önsen & 2 Muğla-Katrancı & 3 Aydın-Koçarlı & 4 İzmir-Kozak & 5 Çanakkale-Kirazıı & \\
\hline$\overline{N C}$ & $13(9-16)^{c}$ & $11(9-13)^{a b}$ & $12(9-13)^{b}$ & $11(8-13)^{a}$ & $11(9-13)^{a}$ & $12(9-14)$ \\
\hline SdL1 & $17.3(6.2-23.6)^{\mathrm{a}}$ & $16.7(9.6-22.0)^{\mathrm{ab}}$ & $15.6(5.5-22.0)^{b}$ & $17.0(8.7-21.0)^{\mathrm{ab}}$ & $16.3(10.0-23.5)^{\mathrm{ab}}$ & $16.6(8.0-22.4)$ \\
\hline $\mathrm{SdL2}$ & $33.8(24.6-45.7)^{c}$ & $31.9(22.9-39.6)^{b c}$ & $29.3(20.5-35.5)^{a}$ & $37.7(19.1-52.3)^{d}$ & $30(18.9-39.6)^{\mathrm{ab}}$ & $32.6(21.2-42.5$ \\
\hline $\mathrm{SdD} 1$ & $3.2(1.9-4.9)^{c}$ & $3.3(2.4-4.3)^{c}$ & $2.9(1.7-4.2)^{\mathrm{ab}}$ & $2.9(1.9-3.5)^{b}$ & $2.6(1.2-3.8)^{a}$ & $3.0(1.8-4.1)$ \\
\hline $\mathrm{SdD} 2$ & $6.1(4.6-7.0)^{b}$ & $6.1(4.8-7.9)^{b}$ & $5.8(3.4-7.7)^{\mathrm{b}}$ & $5.3(3.2-7.4)^{a}$ & $5.8(4.1-7.5)^{b}$ & $5.8(4.0-7.5)$ \\
\hline LB1 & $4(0-7)^{a}$ & $5(2-7)^{a}$ & $4(0-7)^{a}$ & $4(1-7)^{a}$ & $4(1-8)^{a}$ & $4(1-7)$ \\
\hline LB2 & $5(1-11)^{a}$ & $8(1-13)^{c}$ & $10(0-19)^{d}$ & $5(0-14)^{a b}$ & $7(2-13)^{b c}$ & $7(1-14)$ \\
\hline BS & $58^{\mathrm{a}}$ & $8^{\mathrm{b}}$ & $8^{\mathrm{b}}$ & $0^{b}$ & $11^{\mathrm{b}}$ & 17 \\
\hline
\end{tabular}

Means within columns following by same letters are not statistically different at 0.05 significance level in Duncan post hoc test. For abbreviations, please see Table 2. Minimum and maximum values are presented in parenthesis

properties. The number of sound seeds is an important factor in afforestation purposes. Seed production is a limiting factor for regeneration, and it is necessary to improve seedling survival in stone pine stands (Calama and Montero 2007).

\section{Seed traits}

We found that the average SW (0.8 g) differed among the populations, and was higher than the $0.6 \mathrm{~g}$ determined by Mutke et al. (2011) and the $0.7 \mathrm{~g}$ of Ganatsas et al. (2008), while it was lower than the $0.9 \mathrm{~g}$ found by Loewe-Muñoz et al. (2018). The average SD and SL determined by Loewe-Muñoz et al. (2018) were 1 and 2 $\mathrm{cm}$, respectively, while in the present study, they were 0.9 and $1.8 \mathrm{~cm}$, respectively; these latter measurements are similar to those reported by Ganatsas et al. (2008) and Carcel et al. (2012).

Loewe-Muñoz et al. (2019) report that the mean 6year measurement of $\mathrm{SN}$ in plantations in Chile was 113 which is more than double that found in the present study (50), with the Çanakkale-Kirazlı population having the lowest (25). A positive correlation was found between SN and CW; this finding supports several previous studies that have indicated that heavier cones contain more seeds (Calama and Montero 2007; Boutheina et al. 2013; Loewe-Muñoz et al. 2019). In our findings, the average cone to seed yield (SY) ranged between 8.1 and 18.5\%, while Loewe-Muñoz et al. (2019) reported 6-year-mean values ranging from 17.7 to $22.6 \%$.

The 6-year measurement of PY varied from 3.6 to $5.0 \%$ in plantations in Chile (Loewe-Muñoz et al. 2019), which is approximately 1.5 times higher than was measured in our populations. We also observed that populations with larger and heavier cones had the highest PW, consistent with the findings of Loewe-Muñoz et al. (2019), who highlighted that PY depended first on PN, then on PW.

Loewe-Muñoz et al. (2019) stated that cone morphometry is not a good indicator of PY, due to the inverse relationship between $\mathrm{CW}, \mathrm{CD}, \mathrm{CL}$, and PY, so selecting cones for size/weight would not improve PY. However, our results did not support this idea--increased CW,

Table 6 Correlation coefficients ( $r$ values) of cone, seed, and pine nut variables of the five $P$. pinea natural populations across Turkey

\begin{tabular}{|c|c|c|c|c|c|c|c|c|c|c|c|c|}
\hline & $\mathrm{CW}$ & $\mathrm{CL}$ & $C D$ & SN & SW & SL & SD & SY & ES & PN & PW & PY \\
\hline CW & 1 & $0.849^{* *}$ & $0.885^{* *}$ & $0.748^{* *}$ & $0.616^{* *}$ & $0.765^{* *}$ & $0.417^{* *}$ & $0.527^{* *}$ & $-0.412^{* *}$ & $0.646^{* *}$ & $0.369^{* *}$ & $0.455^{* *}$ \\
\hline $\mathrm{CL}$ & & 1 & $0.786^{* *}$ & $0.626^{* *}$ & $0.590^{* *}$ & $0.720^{* *}$ & $0.409^{* *}$ & $0.504^{* *}$ & $-0.390^{* *}$ & $0.547^{* *}$ & $0.379^{* *}$ & $0.448^{* *}$ \\
\hline$C D$ & & & 1 & $0.743^{* *}$ & $0.707^{* *}$ & $0.840^{* *}$ & $0.533^{* *}$ & $0.660^{* *}$ & $-0.334^{* *}$ & $0.593^{* *}$ & $0.303^{* *}$ & $0.433^{* *}$ \\
\hline SN & & & & 1 & $0.335^{* *}$ & $0.651^{* *}$ & 0.076 & $0.880^{* *}$ & $-0.414^{* *}$ & $0.834^{* *}$ & $0.176^{* *}$ & $0.617^{* *}$ \\
\hline SW & & & & & 1 & $0.866^{* *}$ & $0.921^{* *}$ & $0.472^{* *}$ & -0.055 & $0.188^{* *}$ & $0.276^{* *}$ & 0.109 \\
\hline $\mathrm{SL}$ & & & & & & 1 & $0.672^{* *}$ & $0.706^{* *}$ & $-0.235^{* *}$ & $0.488^{* *}$ & $0.292^{* *}$ & $0.354^{* *}$ \\
\hline SD & & & & & & & 1 & $0.241^{* *}$ & 0.064 & -0.024 & $0.220^{* *}$ & -0.046 \\
\hline SY & & & & & & & & 1 & $-0.269^{* *}$ & $0.667^{* *}$ & 0.117 & $0.529^{* *}$ \\
\hline ES & & & & & & & & & 1 & $-0.796^{* *}$ & $-0.241^{* *}$ & $-0.755^{* *}$ \\
\hline PN & & & & & & & & & & 1 & $0.209^{* *}$ & $0.826^{* *}$ \\
\hline PW & & & & & & & & & & & 1 & $0.568^{* *}$ \\
\hline PY & & & & & & & & & & & & 1 \\
\hline
\end{tabular}

* and ** stating significant differences at 0.05 and 0.01 levels, respectively. For abbreviations, please see Table 2 
Table 7 Correlation coefficients ( $r$ values) of cone, seed, pine nut, geographical, and climatic variables of the five $P$. pinea natural populations across Turkey

\begin{tabular}{|c|c|c|c|c|c|c|c|c|c|c|c|}
\hline \multirow{2}{*}{$\begin{array}{l}\text { Morphometric } \\
\text { Traits }\end{array}$} & \multicolumn{3}{|c|}{ Geographical data } & \multicolumn{8}{|c|}{ Climatic data } \\
\hline & Long. & Lat. & Alt. & $\overline{A R}$ & RJ & $P$ & $M$ & $\mathbf{Q}$ & $\mathrm{PE}$ & ME & $S$ \\
\hline$C D$ & 0.311 & -0.659 & 0.872 & 0.441 & -0.098 & 0.275 & 0.819 & -0.625 & -0.740 & $0.939^{*}$ & -0.806 \\
\hline $\mathrm{CL}$ & -0.010 & -0.598 & 0.667 & 0.774 & -0.343 & -0.008 & 0.726 & -0.823 & -0.395 & 0.846 & -0.497 \\
\hline$C W$ & -0.047 & -0.552 & 0.683 & 0.720 & -0.396 & -0.072 & 0.718 & -0.820 & -0.476 & 0.844 & -0.563 \\
\hline SN & -0.201 & -0.550 & 0.606 & 0.670 & -0.661 & -0.250 & 0.701 & $-0.897^{*}$ & -0.432 & 0.758 & -0.504 \\
\hline ES & 0.236 & 0.653 & -0.328 & -0.471 & 0.846 & 0.236 & -0.599 & 0.822 & 0.073 & -0.447 & 0.134 \\
\hline SY & -0.022 & -0.609 & 0.730 & 0.545 & -0.518 & -0.081 & 0.772 & -0.819 & -0.598 & 0.837 & -0.661 \\
\hline SD & 0.754 & -0.503 & 0.813 & -0.075 & 0.530 & 0.732 & 0.613 & -0.046 & -0.826 & 0.736 & -0.846 \\
\hline$S L$ & 0.100 & -0.585 & 0.771 & 0.595 & -0.272 & 0.065 & 0.759 & -0.736 & -0.610 & $0.889^{*}$ & -0.686 \\
\hline 1000-SW & 0.519 & -0.564 & 0.866 & 0.209 & 0.218 & 0.484 & 0.723 & -0.351 & -0.816 & 0.866 & -0.860 \\
\hline PN & -0.254 & -0.638 & 0.492 & 0.582 & -0.848 & -0.288 & 0.691 & $-0.923^{*}$ & -0.280 & 0.629 & -0.345 \\
\hline PW & -0.396 & -0.339 & 0.395 & $0.889^{*}$ & -0.612 & -0.412 & 0.497 & -0.878 & -0.155 & 0.623 & -0.248 \\
\hline PY & -0.295 & -0.613 & 0.417 & 0.560 & $-0.884^{*}$ & -0.323 & 0.641 & $-0.903^{*}$ & -0.200 & 0.554 & -0.262 \\
\hline
\end{tabular}

Long. longitude; Lat. latitude; Alt. altitude; $A R$ annual rainfall $(\mathrm{mm})$ in the third year prior to harvest time; $R J$ rainfall (mm) in June of third year prior to harvest time; $P$ mean annual rainfall in $\mathrm{mm} ; M$ the mean of the maximum of the hottest month in ${ }^{\circ} \mathrm{C} ; Q$ Emberger humidity category; $P E$ sum of rainfall in June, July, and August for the period 1987-2016; ME mean of the maximum temperature of June, July, and August; S summer drought index value. For other abbreviations, please see Table $2 .{ }^{*}$ and ${ }^{* *}$ stating significant differences at 0.05 and 0.01 levels, respectively

CD, and CL resulted in increased PY. The PY is particularly interesting because of an increase of empty and damaged seeds (Loewe-Muñoz et al. 2019), which have been associated with increased drought or phenological shifts due to climatic change (Mutke et al. 2014) and infestation with Leptoglossus occidentalis Heidemann (Farinha et al. 2018).

Many studies have found that the seed size in many species is nonlinearly related to altitude and latitude, being dependent on low temperatures and radiation and a shorter growing season at higher latitudes or altitudes (Moles and Westoby 2003; Murray et al. 2004; Moles et al. 2007). Şefik (1964) determined that the SW of Pinus brutia (Turkish red pine) decreases from low to high altitudes, and from south to north. Also, Kaya and Issık (1997) found that the SW in P. brutia decreases as it ascends above sea level. Some seeds, such as those of Picea mariana and Pinus banksiana, negatively correlate with latitude and altitude, while those of Picea glauca have shown no correlations with latitude or altitude in

Table 8 Correlation coefficients ( $r$ values) of seedling growth, germination traits, and geographical parameters of the five $P$. pinea natural populations across Turkey

\begin{tabular}{|c|c|c|c|c|c|c|c|c|c|c|c|c|c|}
\hline Traits & SdL1 & SdL2 & SdD1 & SdD2 & LB1 & LB2 & BS & NC & FGP & FMGT & Long. & Lat. & Alt \\
\hline SdL1 & 1 & 0.760 & 0.538 & 0.053 & 0.399 & $-0.915^{*}$ & 0.548 & 0.228 & 0.189 & -0.308 & 0.616 & -0.060 & 0.178 \\
\hline $\mathrm{SdL2}$ & & 1 & 0.300 & -0.523 & 0.405 & -0.808 & 0.048 & -0.054 & 0.046 & 0.320 & 0.196 & 0.120 & 0.159 \\
\hline $\mathrm{SdD} 1$ & & & 1 & 0.575 & 0.546 & -0.169 & 0.444 & 0.375 & -0.309 & 0.033 & 0.576 & -0.838 & 0.713 \\
\hline $\mathrm{SdD2}$ & & & & 1 & 0.022 & 0.269 & 0.609 & 0.511 & -0.041 & -0.563 & 0.558 & -0.700 & 0.403 \\
\hline LB1 & & & & & 1 & -0.177 & -0.328 & -0.559 & -0.823 & 0.266 & -0.230 & -0.162 & -0.097 \\
\hline LB2 & & & & & & 1 & -0.425 & -0.132 & -0.397 & 0.287 & -0.464 & -0.297 & 0.051 \\
\hline BS & & & & & & & 1 & 0.876 & 0.652 & -0.683 & $0.976^{* *}$ & -0.410 & 0.513 \\
\hline$N C$ & & & & & & & & 1 & 0.687 & -0.357 & $0.892^{*}$ & -0.564 & 0.758 \\
\hline FGP & & & & & & & & & 1 & -0.482 & 0.583 & 0.210 & 0.144 \\
\hline FMGT & & & & & & & & & & 1 & -0.521 & -0.117 & 0.226 \\
\hline Long. & & & & & & & & & & & 1 & -0.516 & 0.652 \\
\hline Lat. & & & & & & & & & & & & 1 & -0.874 \\
\hline Alt. & & & & & & & & & & & & & 1 \\
\hline
\end{tabular}

FGP field germination percentage, FMGT field mean germination time, Long. longitude, Lat. latitude, Alt. altitude. For other abbreviations, please see Table 2. ${ }^{*}$ and ** stating significant differences at 0.05 and 0.01 levels, respectively 
the Boreal Shield Ecozone. In the same study, in the Atlantic Maritime Ecozone, seed size in Picea mariana and Picea glauca had no relationship with latitude or altitude, while seed size in P. banksiana did show positive correlations with latitude and altitude (Liu et al. 2013). In the present study, we have confirmed that this nonlinear relationship is not consistent within populations of stone pine, which indicate an increase in seed and cone size with increasing altitude and decreasing latitude. Furthermore, in the present study, longitude had no influence on cone or seed size. We can conclude that mean annual rainfall was not a determinant of cone or seed size in stone pine populations.

Considering that the SW decreases as elevation increases, the altitude factor should be taken into consideration for stone pine plantations being used for seed production. It should be noted that, where the soil properties are suitable, plantations above $400 \mathrm{~m}$ might be more productive. The impact of drought is likely to be lessened in such locations, compared to areas close to sea level, and the nutritional environment might be more suitable.

\section{Seed germination and seedling traits}

Ganatsas and Tsakaldimi (2007) found $87.2 \%$ to $100 \%$ stone pine seed germination, with a MGT of 13.4-15.6 days at $20^{\circ} \mathrm{C}$. According to Escudero et al. (2002), GP in stone pine decreased at $25{ }^{\circ} \mathrm{C}$, and differences in the GPs among populations was more than $50 \%$. Population effects have been found to be significant in $P$. pinea and $P$. pinaster, and in their relationship to temperature. In addition, significant interaction has been reported among population, temperature, and germination rate in $P$. pinea. However, it has also been pointed out that, unlike mountain pines (Pinus nigra, Pinus sylvestris), lowland pines (Pinus halepensis, P. pinaster, P. pinea) and Pinus canariensis have exhibited significant effects of temperature on germination response, and germination is higher between 15 and $20{ }^{\circ} \mathrm{C}$ than at warmer and alternating temperatures.

It has also been reported that successful seedling establishment depends on rapid germination and growth, such as in Pinus strobus (Parker et al. 2006) and Pinus densata (Xu et al. 2016). As the germination speed of a seed lot increases, the height of the seedlings from the seed lot may also increase. In other words, the lower the MGT, the taller the seedling height (Çalışkan 2006). The present study concluded that there was no significant intraspecific variation in the germinations between the field and laboratory $\left(20^{\circ} \mathrm{C}\right)$, although all populations showed variety in seed size, with bigger seeds germinating faster (Moles and Westoby 2004). Our results support certain studies in which it was indicated that seed weight had little effect on germination in Picea sitchensis
(Chaisurisri et al. 1992) and P. pinaster (Wahid and Bounoua 2013). Additionally, bigger seeds are prone to producing bigger seedlings in Pinus yunnanensis (Cai et al. 2016).

In the present study, $\mathrm{NC}$ exhibited significant variety across the native stone pine habitats, while Ganatsas et al. (2008) reported that this was lower in over-mature stands. Moreover, it was determined that NC positively correlated with the longitude of the origins of the stone pines. Also, there was a strong correlation between NC and BS. It could be that BS relates better to mean annual rainfall in our study, while Meng et al. (2015) indicated that annual mean temperature and mean temperature of the coldest month have a stronger relationship with BS in P. yunnanensis over 2 years.

A limitation of this study was that it depended on 1year results, whereas inter-annual variations in seed production have been documented by several authors (Mutke et al. 2005; Calama et al. 2008, 2011, 2016; Loewe-Muñoz et al. 2019, 2020). Such variations could be the result of climatic factors affecting the 3-year reproductive development cycle of cones in stone pine.

\section{Conclusions}

The findings of this study contribute to a better understanding of native populations (with an eastern distribution) of stone pine, and should be taken into consideration in forest management especially relating to afforestation, yield, and breeding activities. Stone pine plays an important role in the rehabilitation and restoration of the Mediterranean Basin, the success of which depends on the quality of seeds and seedlings. Considering intraspecific variation, Çanakkale-Kirazlı population should be assessed within a framework of in-situ conservation due to having distinctive value in all cone and seed morphometric traits among the studied populations. The overall empty seed ratio was $46 \%$, ranging from 20 to $68 \%$ among the populations. This dramatic decrease in seed production has been reported in previous works, and is understood to be associated with increasing drought, or phenological shifts due to climatic change and infestation with Leptoglossus occidentalis Heidemann. With seed weight decreasing with elevation, the altitude factor should be taken into consideration in stone pine plantations for seed production. It should be noted that, where the soil properties are suitable, plantations above $400 \mathrm{~m}$ may be more appropriate. In terms of climatic factors, $Q$ and $\mathrm{ME}$ were found to be the main drivers behind significant effects in stone pine cone, seed, and pine nut morphometric traits. We suggest that the $Q$ Index should be used to determine cone to pine nut yield. Moreover, stone pine plantations should be focused on sub-humid areas with $Q$ values of less than 75 . Further studies are needed to interpret these results in 
relation to the stand properties, and long-term research is needed to investigate how the stone pine will react to the novel environmental conditions of the future.

\section{Acknowledgements}

We are thankful to Turkish State of Meteorological Service for sharing meteorological data. We also thank Istanbul Forest Nursery Manager Nejdet BALCl and nursery staffs for their great supports. The authors thank two anonymous reviewers and editor for their valuable comments which significantly improved the original manuscript.

\section{Availability of data}

The datasets of the current study are available from the corresponding author on reasonable request.

\section{Authors' contributions}

All authors contributed to the study conception and design. SB and SC are performed data collection and analysis. HD revised and improved the manuscript. Final manuscript has been read and approved by all authors.

\section{Funding}

This study was supported by the Scientific Research Projects Coordination Unit of Istanbul University-Cerrahpasa. Project No. FBA-2016-21357.

\section{Competing interest}

The authors declare that they have no known competing financial interests or personal relationships that could have appeared to influence the work reported in this paper

\section{Consent for publication}

Not applicable.

Received: 10 August 2020 Accepted: 24 September 2020

Published online: 12 October 2020

\section{References}

Akburak S, Son Y, Makineci E, Çakir M (2018) Impacts of low-intensity prescribed fire on microbial and chemical soil properties in a Quercus frainetto. J For Res 29:687-696 https://doi.org/10.1007/s11676-017-0486-4

Baskin CC, Baskin JM (1998) Seeds: ecology, biogeography, and evolution of dormancy and germination. Academic Press, San Diego

Bewley JD, Black M (1994) Seeds: Physiology of development and germination. Plenum Press, New York

Boutheina A, Hedi El Aouni M, Balandier P (2013) Influence of stand and tree attributes and silviculture on cone and seed productions in forests of Pinus pinea in northern Tunisia. Options Méditérr 105:9-14

Boydak M, Calıškan S (2014) Ağaçlandırma. Ankara, Turkey

Boydak M, Çalışkan S (2015) Afforestation in arid and semi-arid regions. Ankara, Turkey

Boydak M, Dirik H, Calikoglu M (2006) Biology and silviculture of Turkish red pine (Pinus brutia Ten.). Ankara, Turkey

Buru JC, Dhileepan K, Osunkoya OO, Scharaschkin T (2016) Germination biology and occurrence of polyembryony in two forms of cats claw creeper vine, Dolichandra unquis-cati (Bignoniaceae): implications for its invasiveness and management. Am J Plant Sci 7:657-670 https://doi.org/10.4236/ajps.2016. 73058

Cai N, Xu Y, Chen S, He B, Li G, Li Y, Duan A (2016) Variation in seed and seedling traits and their relations to geo-climatic factors among populations in Yunnan Pine (Pinus yunnanensis). J For Res 27:1009-1017. https://doi.org/10. 1007/s11676-016-0228-z

Calama R, Montero G (2007) Cone and seed production from Stone pine (Pinus pinea) stands in Central Range (Spain). Eur J For Res 126:23-35. https://doi. org/10.1007/s10342-005-0100-8

Calama R, Mutke S, Sánchez M, Garriga E, Montero G (2007) Modelling spatial and temporal variability on Stone pine (Pinus pinea L.) cone quality: preliminary results. EFIMED Scientific Seminar: modelling, valuing and managing Mediterranean forest ecosystem for non-timber goods and services. S.I.: CIFOR-INIA

Calama R, Gordo FJ, Mutke S, Montero G (2008) An empirical ecological-type model for predicting Stone pine (Pinus pinea L.) cone production in the
Northern Plateau (Spain). For Ecol Manag 255:660-673 https://doi.org/10. 1016/j.foreco.2007.09.079

Calama R, Mutke S, Tomé JA, Gordo FJ, Montero G, Tomé M (2011) Modelling spatial and temporal variability in a zero-inflated variable: the case of stone pine (Pinus pinea L.) cone production. Ecol Model 222:606-618. http://dx.doi. org/10.1016/j.ecolmodel.2010.09.020

Calama R, Gordo J, Madrigal G, Mutke S, Conde M, Montero G, Pardos M (2016) Enhanced tools for predicting annual stone pine (Pinus pinea L.) cone production at tree and forest scale in Inner Spain. For Syst 25:e079 https:// doi.org/10.5424/fs/2016253-09671

Çalışan S (2006) Doğal Kızılçamlarda (Pinus brutia Ten.) Populasyonlar Arası ve İ̧ı Genetik Çeşitlilik. J Fac For Istanbul U 56(1):169-96.

Çalışan S, Boydak M (2017) Afforestation of arid and semiarid ecosystems in Turkey. Turk J Agric For 41:317-330. https://doi.org/10.3906/tar-1702-39

Carcel LM, Bon J, Acuna L, Nevares I, Del Alamo M, Crespo R (2012) Moisture dependence on mechanical properties of pine nuts from Pinus pinea $\mathrm{L}$. J Food Eng 2:294-297 https://doi.org/10.1016/j.jfoodeng.2011.04.018

Caudullo G, Welk E, San-Miguel-Ayanz J (2017) Chorological maps for the main European woody species. Data in Brief 12:662-666. https://doi.org/10.1016/j. dib.2017.05.007

Chaisurisri K, Edwards DGW, El-Kassaby YQ (1992) Genetic control of seed size and germination in Sitka spruce. Silvae Genetica 41:348-355

Daget P, Ahdali L, David P (1988) Mediterranean bioclimate and its variation in the Palaearctic region. In: Specht RL (ed) Mediterranean-type ecosystems, a data source book. Kluwer Academic Publishers, Dordrecht, pp 139-148

Escudero A, Pérez-García F, Luzuriaga AL (2002) Effects of light, temperature and population variability on the germination of seven Spanish pines. Seed Sci Res 12:261-271 https://doi.org/10.1079/SSR2002116

Farelli E, Muller C, Laroppe E (1997) Effect of ethephon on dormancy breaking in beechnuts. In: Ellis RH, Black M, Murdoch AJ, Hong TD (eds) Basic and Applied Aspects of Seed Biology. Kluwer Academic Publishers, Dordrecht, pp 303-309

Farinha ACO, Silva JEP, Correia AC, Sousa EMR, Roques A, Branco M (2018) Is Leptoglossus occidentalis entirely responsible for the high damage observed on cones and seeds of Pinus pinea? Results from a fertirrigation trial in Portugal. For Ecol Manag 429:198-206 https://doi.org/10.1016/j.foreco.2018. 07.014

Ganatsas P. Tsakaldimi M (2007) Effect of light conditions and salinity on germination behaviour and early growth of umbrella pine (Pinus pinea $\mathrm{L}$.) seed. J Hortic Sci Biotechnol 82:605-610. https://doi.org/10.1080/14620316. 2007.11512280

Ganatsas P, Tsakaldimi M, Thanos C (2008) Seed and cone diversity and seed germination of Pinus pinea in Strofylia site of the Natura 2000 Network. Biodivers Conserv 17:2427-2439. https://doi.org/10.1007/s10531-008-9390-8

Gonçalves AC, Pommerening A (2012) Spatial dynamics of cone production in Mediterranean climates: a case study of Pinus pinea L. in Portugal. For Ecol Manag 266:83-93 https://doi.org/10.1016/j.foreco.2011.11.007

Huang RF (1993) The population genetics and evolution of Pinus yunnanensis. J Yunnan Univ 15:50-63

ISTA (1999) International rules for seed testing. Seed Sci Technol 27 (Supplemantary)

Kaya Z, Isıı F (1997) The pattern of genetic variation in shoot growth of Pinus brutia Ten. populations sampled from the Toros Mountains in Turkey. Silvae Genet 46:73-81

Liu J, Bai Y, Lamb EG, Simpson D, Liu G, Wei Y, Wang D, McKenney DW, Papadopol P (2013) Patterns of cross-continental variation in tree seed mass in the Canadian boreal forest. PLoS One 8:e61060. https://doi.org/10.1371/ journal.pone.0061060

Loewe-Muñoz V, Balzarini M, Álvarez-Contreras A, Delard-Rodríguez C, NavarroCerrillo RM (2016) Fruit productivity of stone pine (Pinus pinea L.) along a climatic gradient in Chile. Agric For Meteorol 223:203-216 https://doi.org/10. 1016/.jagrformet.2016.04.011

Loewe-Muñoz V, Alvarez AP, Balzarini M, Delard C, Cerrillo R (2017) Mineral fertilization and irrigation effects on fruiting and growth in stone pine (Pinus pinea L.) crop. Fruits 72:281-287 https:/doi.org/10.17660/th2017/72.5.3

Loewe-Muñoz V, Álvarez A, Navarro-Cerrillo R (2018) Morphometric and chemical fruit variability of selected stone pine trees (Pinus pinea L.) grown in nonnative environments. Plant Biosyst 152:547-555. https://doi.org/10.1080/ 11263504.2018 .1435587

Loewe-Muñoz V, Balzarini M, Delard C, Álvarez A (2019) Variability of stone pine (Pinus pinea $\mathrm{L}$.) fruit traits impacting pine nut yield. Ann For Sci 76:37. https://doi.org/10.1007/s13595-019-0816-0 
Loewe-Muñoz V, Balzarini M, Delard C, Del Río R, Álvarez A (2020) Inter-annual variability of Pinus pinea $\mathrm{L}$. cone productivity in a non-native habitat. New Forests. https://doi.org/10.1007/s11056-020-09774-6

Meng J, Mao JF, Zhao W, Xing F, Chen X, Liu H, Xing Z, Wang XR, Li Y (2015) Adaptive differentiation in seedling traits in a hybrid pine species complex, Pinus densata and its parental species, on the Tibetan Plateau. PLoS One 10: e0118501. https://doi.org/10.1371/journal.pone.0118501

Moles AT, Westoby M (2003) Latitude, seed predation and seed mass. J Biogeogr 30:105-128 https://doi.org/10.1046/j.1365-2699.2003.00781.x

Moles AT, Westoby M (2004) Seedling survival and seed size: a synthesis of the literature. J Ecol 92:372-383 https://doi.org/10.1111/j.0022-0477.2004.00884.x

Moles AT, Ackerly DD, Tweddle JC, Dickie JB, Smith R et al (2007) Global patterns in seed size. Glob Ecol Biogeogr 16:109-116 https://doi.org/10.1111/j.14668238.2006.00259.x

Murray BR, Brown AHD, Dickman CR, Crowther MS (2004) Geographical gradients in seed mass in relation to climate. J Biogeogr 31:379-388 https://doi.org/10. 1046/j.0305-0270.2003.00993.x

Mutke S, Gordo J, Gil L (2005) Variability of Mediterranean stone pine cone production: yield loss as response to climate change. Agric For Meteorol 132: 263-272 https://doi.org/10.1016/j.agrformet.2005.08.002

Mutke S, Calama R, González-Martínez S, Montero G, Gordo FJ, Bono D, Gil L. (2011) Mediterranean stone pine: botany and horticulture. In: Janick J (ed) Horticultural reviews. Wiley-Blackwell, pp 153-201

Mutke S, Gordo J, Bono D, Gil L (2012) Mediterranean Stone pine: botany and horticulture. Hortic Rev 39:153-201 https://doi.org/10.1002/9781118100592.ch4

Mutke S, Martínez J, Gordo J, Nicolas UL, Herrero N, Pastor A, Calama R (2014) Severe seed yield loss in Mediterranean Stone pine cones. 5th International Conference on Mediterranean Pines (Medpine5)

Parker WH, Noland TL, Morneault AE (2006) The effects of seed mass on germination, seedling emergence and early seedling growth of eastern white pine (Pinus strobus L.). New For 32:33-49 https://doi.org/10.1007/ s11056-005-3391-1

Parlak S, Kilci M, Sayman M, Akkas ME, Bucak C, Boza Z (2013) Climate factors and their relations regarding cone yield of stone pine trees (Pinus pinea $\mathrm{L}$.) in Kozak Basin. Options Méditérr 105:15-19

Pereira S, Prieto A, Calama R, Diaz-Balteiro L (2015) Optimal management in Pinus pinea $\mathrm{L}$. stands combining silvicultural schedules for timber and cone production. Silva Fenn 49:1226. https://doi.org/10.14214/sf.1226

Saracino A, Bellino A, Allevato E, Mingo A, Conti S, Rossi S, Bonanomi G, Carputo D, Mazzoleni S (2017) Repeated stand-replacing crown fires affect seed morphology and germination in Aleppo pine. Front Plant Sci 8:1160. https://doi.org/10.3389/fpls.2017.01160

Şefik Y (1964) Kızılçam (Pinus brutia ten.) kozalak ve tohumu üzerine araştırmalar Forestist 2:35-67

SPSS (2010) IBM SPSS Statistics 19 Core System User's Guide. SPSS Inc., Chicago Ürgenç S (1982) Orman Ağaçları Islahı. Istanbul, Turkey

Valdiviesso T, Pimpão M, Trindade CS, Varela MC (2017) Reproductive phenology of Pinus pinea. In: Carrasquinho I, Correia AC, Mutke S (Eds), Mediterranean pine nuts from forests and plantations. pp 63-68

Vendramin GG, Fady B, González-Martínez SC, Hu FS, Scotti I, Sebastiani F, Petit RJ (2008) Genetically depauperate but widespread: the case of an emblematic Mediterranean pine. Evolution 62:680-688 https://doi.org/10.1111/j.15585646.2007.00294.x

Wahid N, Bounoua L (2013) The relationship between seed weight, germination and biochemical reserves of maritime pine (Pinus pinaster Ait.) in Morocco. New For 44:385-397 https://doi.org/10.1007/s1 1056-012-9348-2

Xu Y, Cai N, He B, Zhang R, Zhao W, Mao J, Woeste K (2016) Germination and early seedling growth of Pinus densata Mast. provenances. J For Res 27:283294 https://doi.org/10.1007/s11676-015-0186-x

\section{Publisher's Note}

Springer Nature remains neutral with regard to jurisdictional claims in published maps and institutional affiliations.

\section{Submit your manuscript to a SpringerOpen ${ }^{\odot}$ journal and benefit from:}

- Convenient online submission

- Rigorous peer review

- Open access: articles freely available online

High visibility within the field

- Retaining the copyright to your article

Submit your next manuscript at $\boldsymbol{\nabla}$ springeropen.com 